\title{
Pediatric VISCERAL LEISHMANIASIS DIAGNOSIS IN TUNISIA: COMPARATIVE STUDY BETWEEN OPTIMISED PCR ASSAYS AND PARASITOLOGICAL METHODS
}

\author{
KAOUECH E.*, KALLEL K.*,TOUMI N.H.**, BELHADJ S.*, ANANE S.*, BABBA H.*** \& CHAKER E.*
}

\section{Summary:}

There has been a steady increase of visceral leishmaniasis during the past 20 years in Tunisia. In this study, we assess the value of two optimised PCR versus those of classical methods for the diagnosis of human visceral leishmaniasis. 106 samples were collected from 53 cases of pediatric visceral leishmaniasis Peripheral blood and bone marrow samples were analysed both by parasitological methods (direct examination,

leukocytoconcentration (LCC) and culture) and by PCR methods with two primer pair (R221/R332 and Lei 70L/Lei 70R). We diagnosed visceral leishmaniasis in all patients: 44 cases were diagnosed by culture ( $83 \%), 42$ by direct examination of bone marrow (79 \%), 17 by LCC (32\%), and 53 positive cases with both PCR assays (R221/R332 and/or Lei 70L/Lei 7OR) (100\%). Regarding each PCR assay, for blood samples, the difference between the sensitivities of PCR Lei 7OL/Lei 7OR (86,8 \%) and PCR R221/R332 (17\%) is statistically significant with p-value 0.025 . For bone marrow, the sensitivities of the two PCR methods were respectively 96,2\% (Lei 70L/Lei 7OR) and 75,5\% (R221/R332). On the whole, PCR Lei 7OL/Lei 7OR was more effective than PCR R221/R332 and conventional methods for the two biological samples. Moreover, the requirement of less invasive sample using blood has the advantage of being repeatable for screening and for post therapeutic monitoring.

KEY WORDS : visceral leishmaniasis, PCR, direct examination, leukocytoconcentration, culture, blood, bone marrow, Tunisia.
Résumé : Diagnostic de la leishmaniose VISCÉrale de l’enfant en TuNISIE : COMPARAISON DE DEUX MÉTHODES PCR OPTIMISÉES AUX MÉTHODES CLASSIQUES

L'incidence de la leishmaniose viscérale en Tunisie est de plus en plus importante depuis la recrudescence des cas rapportés au cours de ces 20 dernières années. Pour une meilleure approche diagnostique, nous nous proposons d'appliquer deux méthodes PCR optimisées dans le diagnostic de la leishmaniose viscérale et de les comparer aux méthodes classiques. 106 échantillons ont été collectés chez 53 enfants hospitalisés atteints de leishmaniose viscérale. Sang périphérique et moelle osseuse ont été analysés par les méthodes parasitologiques lexamen direct, leucocytoconcentration (LCC) et culture) et par les méthodes PCR moyennant deux couples d'amorces (R221/R332 et Lei7OL/Lei7OR). Tous les patients étaient atteints de la leishmaniose viscérale : 44 cas ont été diagnostiqués par la culture (83\%), 42 par l'examen direct de la moelle osseuse (79\%), 17 par la LCC (32\%) et 53 par les deux méthodes PCR (R221/R332 et/ou Lei7OL/Lei7OR) (100\%). En s'intéressant aux méthodes PCR, la sensibilité de la PCR Lei7OL/Lei7OR dans le sang périphérique est significativement plus élevée que celle de la PCR R221/R332 (respectivement 86,8 \% et $17 \% ; p=0,025$ ). Pour les prélèvements de la moelle osseuse, les sensibilités des deux méthodes PCR sont respectivement 96,2\% (Lei7OL/Lei7OR) et 75,5\% (R221/R332). Ainsi, la PCR Lei7OL/Lei7OR est plus efficiente que la PCR R221/R332 et les méthodes classiques et $\mathrm{ce}$, pour les deux sites de prélèvements. De plus, nous avons pu relever l'apport considérable du prélèvement du sang périphérique vu son caractère peu invasif et sa facilité de réalisation pour le diagnostic et le suivi post-thérapeutique.

MOTS CLÉS : leishmaniose viscérale, PCR, examen direct, leucocytoconcentration, culture, sang, moelle osseuse, Tunisie.

mission of visceral leishmaniasis in Tunisia is localized in the North and has noticeably extended towards the Centre and the South since 1980. (Ayadi et al., 1991). During the past 20 years, there has been a steady increase in visceral leishmaniasis which affects children under the age of five years, with an incidence of 120 cases per year (Direction des soins de santé de base, 2000).

Visceral leishmaniasis in Tunisia was first reported to be caused by Leishmania infantum (Nicolle, 1908); in fact, the first Leishmania infantum Tunisian strain was identified by Lanotte et al. (1981). Actually, the isoenzymatic characterization revealed the existence of three zymodemes of the Leishmania infantum complex: Leishmania infantum MON-1, the most common (93.8 \%), 
followed by Leishmania infantum MON-24 (3.1\%) and Leishmania infantum MON-80 (3.1\%), and $72 \%$ of the strains were obtained from children (Belhadj et al., 2002).

Until the early 1990's, visceral leishmaniasis diagnosis relied on classical parasitologic methods such as Giemsastained bone marrow and in vitro culture of bone marrow and peripheral blood. Over the last decade, diagnosis has been established by molecular methods. PCR can be performed on any biological sample, bone marrow and blood, and has been applied to routine hospital diagnosis in many laboratories all over the world (Cascio et al., 2002; Lachaud et al., 2000, 2001; Spanakos et al., 2002).

To assess the usefulness of PCR in amplifying Leishmania Genome, we report the results of two optimised PCR assays (R221/R332 and Lei70L/Lei70R) comparing them with classical methods, performed on biological samples, peripheral blood as a less invasive sample compared to bone marrow aspirates.

\section{MATERIALS AND METHODS}

\section{SAMPLES}

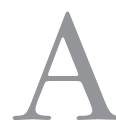
prospective study was carried out in the parasitology laboratory at La Rabta's hospital in Tunis, Tunisia from June 2003 to December 2005. The study subjects were 53 pediatric patients, referred to from different hospitals of Tunisia: Children's Hospital of Tunis, the RABTA Teaching Hospital of Tunis and the Regional Hospital of Zaghouan. All patients presented fever, hepatosplenomegaly and pancytopenia. The mean age of the patients was three years: 27 males and 26 females. No child was HIV positive. On the other hand, 15 children presenting leukaemia (with fever, hepatosplenomegaly and pancytopenia) and recruited in the Pediatric Department of the Children's Hospital of Tunisia were included as negative controls.

106 clinical specimens ( 53 peripheral blood and 53 bone marrow) were collected from 53 study subjects, and 24 clinical specimens (11 peripheral blood and 13 bone marrow) were collected from 15 negative controls as follows: peripheral blood samples were collected in sodium citrated containing tubes for in vitro cultivation $(5 \mathrm{ml})$ and EDTA containing tubes for leukocytoconcentration (LCC) and PCR $(5 \mathrm{ml})$. Bone marrow samples $(1.5 \mathrm{ml})$ were collected with an equal volume of $0,9 \% \mathrm{NaCl}$ containing benzyl penicillin at $200.000 \mathrm{IU} / \mathrm{ml}$. All samples were subjected simultaneously to direct examination of bone marrow, in vitro cultivation, LCC and PCR analysis of both peripheral blood and bone marrow.

\section{METHODS}

\section{Direct examination}

Smears were prepared with a drop of bone marrow and were stained with May Grünwald Giemsa.

\section{IN VITRO CULTIVATION}

For blood cultures, the buffy coat collected after simple centrifugation of $5 \mathrm{ml}$ of peripheral blood was seeded in two blood agar NNN medium (Novy Mc Neal Nicolle) culture tubes. Bone marrow aspirates were seeded in two NNN tubes. The cultures were incubated at $24^{\circ} \mathrm{C}$ and were passaged every week. A culture was declared negative after four passages.

\section{LEUKOCYTOCONCENTRATION}

LCC was prepared in three steps, with $300 \mu \mathrm{l}$ of whole blood, blood lysis with hemolysed solution (containing saponine, formaldehyde, glycerol, $0.9 \% \mathrm{NaCl}$ and distillated water), a cytoconcentration with a cytocentrifuge Cytospin 2 and staining with May Grünwald Giemsa.

\section{DNA ISOlation}

For blood samples, $300 \mu$ of buffy coat were collected after simple centrifugation. DNA isolation was carried out by Qiagen blood $^{\circledR}$. The DNA obtained was diluted in $200 \mu \mathrm{l}$ buffer elution and stored at $-20^{\circ} \mathrm{C}$ until use. A $300 \mu \mathrm{l}$ sample of whole human blood (the mean number of leukocytes in visceral cases was 2,000 leukocytes/ $\mu \mathrm{l}$ ) typically yields $3.6 \mu \mathrm{g}$ of DNA in $200 \mu \mathrm{l}$ elution buffer $(18 \mathrm{ng} / \mu \mathrm{l})$. Bone marrow was prepared by the same methods.

\section{PCR AMPLIFICATION}

Two couples of primers were used for PCR analysis: - First couple of primers: R221/R332 (Van Eys et al., 1992).

The DNA target for PCR amplification was the gene coding for $18 \mathrm{~S}$ RNA (20 to 40 fold repeated sequence). The primers used were 5'-GGTTCCTTTCCTGATTTACG3' (R221) and 5'-GGCCGGTAAAGGCCGAATAG-3' (R332) which produce a $603 \mathrm{bp}$ fragment upon amplification. - Second couple of primers: Lei70L/Lei70R (Spanakos G. et al., 2002)

Primers were designed from a conserved sequence of the ssu-r RNA L. infantum gene. Forward primer designated as Lei70L was 5'-CGCAACCTCGGTTCGGTGTG-3' and reverse designated as Lei70R was 5'-CGCGGTGCTGGACACAGGGTA-3'. This couple of primers amplifies a 345 bp DNA fragment specific for L. infantum.

\section{- PCR optimisation}

PCR optimisation was carried out with two Leismania reference strains: Leishmania infantum MON-1 (MHOM/FR/ 78/LEM75) and Leishmania infantum MON-24 (MHOM/ 
DZ/82/LIPA59) (Pratlong et al., 1994; Belhadj et al., 2002).

- Leishmania serial dilution assay

Promastigotes from a 4-day-old culture of the two strains were washed twice in $1 \times$ PBS and counted on a Malassez cell. They were then diluted with $1 \times$ PBS and the DNA was extracted by QIAGEN Blood ${ }^{\circledR}$. The concentrations of parasites tested were: 2,45 $10^{4}$ to $2,4510^{-2}$ Leishmania/ $\mathrm{\mu l}$ corresponding to: $1,2210^{4}$ to $1,2210^{-2}$ Leishmania genome/PCR tube. Two PCR methods were optimised by using different concentrations of $\mathrm{MgCl}_{2}$ and Taq polymerase, and testing Leishmania serial dilution. After optimisation, the first PCR reaction with R221/ $\mathrm{R} 332$ was performed in a final volume of $50 \mu \mathrm{l}$ containing $1 \times$ buffer, deoxynucleoside triphosphate at a concentration of $200 \mu \mathrm{M}, 4 \mathrm{mM}$ of $\mathrm{MgCl}_{2}, 0.6 \mu \mathrm{M}$ of each primer (R221 and R332) and $1 \mathrm{U}$ of Taq polymerase including $5 \mu \mathrm{l}$ of sample DNA. PCR was performed in a Biometra thermal cycler, under the following conditions: initial denaturation at $94^{\circ} \mathrm{C}$ for $3 \mathrm{~min}, 40$ cycles at $94^{\circ} \mathrm{C}$ for $30 \mathrm{~s}, 54^{\circ} \mathrm{C}$ for $30 \mathrm{~s}$ and $72^{\circ} \mathrm{C}$ for $1 \mathrm{~min} 30 \mathrm{~s}$, and a final elongation step at $72^{\circ} \mathrm{C}$ for $10 \mathrm{~min}$.

The second method used primers Lei70L/Lei70R optimised in a final volume of $50 \mu$ containing $1 \times$ buffer, deoxynucleoside triphosphate at a concentration of $200 \mu \mathrm{M}, 2.5 \mathrm{mM}$ of $\mathrm{MgCl}_{2}, 0.5 \mu \mathrm{M}$ of each primer (Lei 70L and Lei 70R) and 1.25 U of Taq polymerase including $5 \mu \mathrm{l}$ of sample DNA. PCR was performed in a Biometra thermal cycler, under the following conditions: initial denaturation at $94^{\circ} \mathrm{C}$ for $5 \mathrm{~min}, 40$ cycles at $94^{\circ} \mathrm{C}$ for $1 \mathrm{~min}, 65^{\circ} \mathrm{C}$ for $1 \mathrm{~min}$ and $72^{\circ} \mathrm{C}$ for $1 \min 30 \mathrm{~s}$, and a final elongation step at $72^{\circ} \mathrm{C}$ for $10 \mathrm{~min}$.

- PCR product analysis

The reaction products were visualized under UV light after electrophoresis of the $20 \mu \mathrm{l}$ of the reaction solution in a $2 \%$ agarose gel containing ethidium bromide. To avoid contamination, all precautions were taken: DNA isolation, PCR assays and electrophoresis were carried out in separate areas using dedicated pipettes and aliquoted reagents; as well as decontamination (UV exposure and laminar flow hood).

- PCR analysis

Each sample was tested using two PCR methods R221/ R332 and Lei70L/Lei70R. For each experiment, positive and negative controls were used; positive control contained DNA of Leishmania and negative control contained distilled water. For negative samples, PCR amplifications were performed with diluted DNA extracts (1/5 and $1 / 10)$.

- Internal control

The DNA extraction control procedure consisted of the amplification of a fragment $(120 \mathrm{pb})$ of the human $\mathrm{b}$ globin gene with the primers BG1 and BG2 described by Schaffer et al., 1995.

\section{STATistical ANALYsis}

The sensitivity and the specificity of PCR R221/R332 and PCR Lei70L/Lei70R were calculated according to the results of the culture and/or direct examination. Statistical comparisons were performed using Fisher's exact test.

\section{RESULTS}

\section{Performance of the optimized PCR assays}

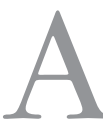
fter the optimisation, the first method using primers R221/R332 can detect 0.122 Leishmania/tube PCR whereas the second method using primers Lei70L/Lei70R can detect 0.0122 Leishmanial tube PCR.

\section{APPLICATION OF THE OPTIMIZED PCR ASSAYS AND CLASSIC METHODS FOR THE DIAGNOSIS OF VISCERAL LEISHMANIASIS}

Leishmania infection was considered definite when the clinical diagnosis was confirmed by positive bone marrow smears and/or in vitro culture of bone marrow and/or peripheral blood (Table I).

53 cases were diagnosed, 44 cases by culture (83\%), 42 by direct examination of bone marrow (79\%), 17 by LCC (32\%), and 53 positive cases with both PCR methods (PCR R221/R332 and/or PCR Lei70L/Lei70R) (100\%).

Biological samples (53 peripheral blood and 53 bone marrow) were used for the diagnosis of visceral leishmaniasis. PCR amplification with the first couple of primers (R221/R332) and/or the second one Lei70L/Lei70R was positive in 98 of 106 samples (92.4\%); whereas direct examination of bone marrow had a sensitivity of $79 \%$ ( 42 of 53 samples), parasite culture had a sensitivity of $55.6 \%$ (59 of 106) and leukocytoconcentration was positive in 21 of 106 samples (19.8\%) (Table II). In vitro cultivation, LCC and PCR assays (R221/R332 and Lei70L/Lei70R) were performed in peripheral blood for all patients; 47 samples gave positive results: 18 samples with both methods (in vitro cultivation and PCR assays). For 29 samples, only PCR assays detected parasitemia (Table III)

For two samples, in vitro cultivation and PCR assays remained negative; the diagnosis was confirmed by direct examination of bone marrow.

Concerning bone marrow aspirates, 51 samples were positive: 36 samples by NNN culture and PCR assays. For 15 samples, Leishmania DNA was detected in bone marrow by PCR (Table III).

For two samples, only classic methods were positive (a positive direct examination and a positive culture) whereas PCR assays remained negative. 
Overall, for peripheral blood, the sensitivity of PCR was $88.7 \%$ (47/53), in vitro cultivation had a sensitivity of $41,5 \%(22 / 53)$ and LCC a sensitivity of $7.5 \%(4 / 53)$ (Table II).

For bone marrow, the sensitivity of both PCR methods was $96.2 \%(51 / 53)$ versus that of direct examination $79 \%(42 / 53)$ whereas culture and leukocytoconcen- tration had respectively a sensitivity of $69.8 \%(37 / 53)$ and $32 \%(17 / 53)$ (Table II).

COMPARISON OF THE TWO PCR METHODS FOR VISCERAL LEISHMANIASIS DIAGNOSIS

Concerning PCR methods, visceral leishmaniasis diagnosis was established by PCR (Lei70L/Lei70R) for all

\begin{tabular}{|c|c|c|c|c|c|c|c|c|c|}
\hline \multirow[b]{2}{*}{ Patients } & \multicolumn{4}{|c|}{ Peripheral blood } & \multicolumn{5}{|c|}{ Bone marrow } \\
\hline & LCC & Culture & $\begin{array}{c}\text { PCR } \\
\text { R221/R332 }\end{array}$ & $\begin{array}{c}\text { PCR } \\
\text { Lei70L/Lei70R }\end{array}$ & LCC & Culture & $\begin{array}{c}\text { Direct } \\
\text { examination }\end{array}$ & $\begin{array}{c}\text { PCR } \\
\text { R221/R332 }\end{array}$ & $\begin{array}{c}\text { PCR } \\
\text { Lei70L/Lei70R }\end{array}$ \\
\hline 1 & - & + & + & + & - & + & + & + & + \\
\hline 2 & + & + & + & + & + & + & + & + & + \\
\hline 3 & - & - & - & + & + & + & + & + & + \\
\hline 4 & _- & + & - & + & - & - & + & + & + \\
\hline 5 & - & - & - & + & - & + & + & + & + \\
\hline 6 & - & + & + & - & - & + & + & + & + \\
\hline 7 & - & + & - & + & - & - & + & - & + \\
\hline 8 & - & - & - & + & - & + & - & - & + \\
\hline 9 & - & - & - & + & + & - & + & + & + \\
\hline 10 & - & - & - & + & - & + & _- & + & + \\
\hline 11 & _- & - & - & + & - & + & - & + & + \\
\hline 12 & - & - & - & + & + & + & + & + & + \\
\hline 13 & - & - & - & + & + & + & + & + & + \\
\hline 14 & - & + & - & - & + & + & + & + & + \\
\hline 15 & - & + & - & + & + & + & + & + & + \\
\hline 16 & - & - & - & + & + & + & + & + & + \\
\hline 17 & - & - & - & + & - & + & - & - & + \\
\hline 18 & - & + & - & + & + & - & + & + & + \\
\hline 19 & - & - & - & + & - & + & + & + & + \\
\hline 20 & + & + & + & + & + & + & + & + & + \\
\hline 21 & - & - & - & + & + & + & + & + & + \\
\hline 22 & - & - & - & + & + & + & - & + & + \\
\hline 23 & - & + & - & + & + & + & - & + & + \\
\hline 24 & - & + & - & + & - & + & + & + & + \\
\hline 25 & - & + & - & - & - & - & - & - & + \\
\hline 26 & + & + & - & - & + & - & + & + & + \\
\hline 27 & - & - & - & - & - & + & - & - & + \\
\hline 28 & - & + & - & + & - & - & + & - & - \\
\hline 29 & - & - & - & - & _ & + & + & - & + \\
\hline 30 & - & - & - & + & - & - & + & + & + \\
\hline 31 & - & - & + & + & - & - & + & + & + \\
\hline 32 & - & + & - & + & - & + & - & - & - \\
\hline 33 & - & + & - & - & - & + & + & + & + \\
\hline 34 & - & - & - & + & - & + & + & + & + \\
\hline 35 & - & + & + & + & - & + & + & + & + \\
\hline 36 & - & - & + & + & - & + & + & + & + \\
\hline 37 & - & + & + & + & - & + & + & + & + \\
\hline 38 & - & - & - & + & - & - & + & - & + \\
\hline 39 & - & - & - & + & - & + & + & + & + \\
\hline 40 & - & - & - & + & - & + & + & + & + \\
\hline 41 & - & - & - & + & - & - & + & - & + \\
\hline 42 & - & - & - & + & - & - & + & + & + \\
\hline 43 & - & - & - & + & - & + & + & + & + \\
\hline 44 & + & + & - & + & + & + & + & + & + \\
\hline 45 & - & - & - & + & - & - & + & - & + \\
\hline 46 & - & - & - & + & - & - & + & - & + \\
\hline 47 & - & + & - & + & - & + & - & + & + \\
\hline 48 & - & - & - & + & - & + & + & + & + \\
\hline 49 & - & - & - & + & + & + & + & + & + \\
\hline 50 & - & - & - & + & - & - & + & - & + \\
\hline 51 & - & + & - & + & + & - & - & + & + \\
\hline 52 & - & + & + & + & - & + & + & + & + \\
\hline 53 & - & - & - & + & - & + & + & + & + \\
\hline
\end{tabular}

Table I. - Results of PCR assays and classical methods for peditaric visceral leishmaniasis diagnosis. 


\begin{tabular}{lcc}
\hline \multicolumn{1}{c}{ Methods } & Bone marrow & $\begin{array}{c}\text { Peripheral } \\
\text { blood }\end{array}$ \\
\hline Smears & $42 / 53(79.2 \%)$ & - \\
Culture & $37 / 53(69.8 \%)$ & $22 / 53(41.5 \%)$ \\
LCC & $17 / 53(32 \%)$ & $4 / 53(7.5 \%)$ \\
PCR Lei70L/Lei70R & $51 / 53(96.2 \%)$ & $46 / 53(86.8 \%)$ \\
PCR R221/R332 & $40 / 53(75.5 \%)$ & $9 / 53(17 \%)$ \\
Both PCR & $51 / 53(96.2 \%)$ & $47 / 53(88.7 \%)$ \\
\hline
\end{tabular}

Table II. - Performances of PCR methods and classical methods for visceral leishmaniasis diagnosis according to the nature of samples.

\begin{tabular}{lccc}
\hline \multirow{2}{*}{ Methods } & \multicolumn{2}{c}{ Peripheral blood } & \\
\cline { 2 - 3 } & PCR positive & PCR negative & Total \\
\hline Culture positive & 18 & 4 & 22 \\
Culture négative & 29 & 2 & 31 \\
Total & 47 & 6 & 53 \\
\hline
\end{tabular}

\begin{tabular}{lccc} 
& \multicolumn{2}{c}{ Bone marrow } & \\
\cline { 2 - 3 } \multicolumn{1}{c}{ Methods } & PCR positive & PCR negative & Total \\
\hline Culture positive & 36 & 1 & 37 \\
Culture négative & 15 & 1 & 16 \\
Total & 51 & 2 & 53 \\
\hline
\end{tabular}

Table III. - Comparison of PCR assays (R221/R332 and/or Lei70L/ Lei70R) and in vitro cultivation performed on peripheral blood and bone marrow for VL diagnosis.

patients (100\%) whereas PCR (R221/ R332) was positive in 40 cases $(75,5 \%)$; therefore the PCR Lei70L/ Lei70R performance is better than that of PCR R221/ R332 with a significative fisher test $(\mathrm{p}<0.0001)$.

Regarding each biological sample, for peripheral blood, the difference between the sensitivities of the two PCR methods PCR (Lei70L/Lei70R) (sensitivity: $86.8 \%$ ) and PCR (R221/ R332) (sensitivity: 17\%) is statistically significant with p-value: 0.025. (Table II).

For bone marrow samples, the sensitivities of the two PCR assays were respectively $75.5 \%$ with R221/R332 and $96.2 \%$ with Lei70L/Lei70R. The specificity of PCR R221/R332 versus that of PCR Lei 70L/Lei 70R was $100 \%$ versus $100 \%$ with peripheral blood and $100 \%$ versus $92,3 \%$ with bone marrow (only one false positive result was observed among the 13 bone marrow specimens collected from negative control patients tested with PCR Lei70L/Lei70R).

Complete inhibition was not observed for all samples; nevertheless, the ß-globine gene was not sensitive enough to detect low grade PCR inhibitors.

Only partial inhibition was observed for two peripheral blood and one bone marrow of the total samples tested with PCR R221/R332 and for five peripheral blood of the total specimens tested with PCR Lei70L/Lei70R; inhibition was solved by dilution of DNA samples to $1 / 5$ or $1 / 10$.
No PCR contamination was ever observed. Overall, all negative control test tubes remained negative over the period of the study.

\section{DISCUSSION}

Durther to optimisation of PCR assays with a serial dilution of Leishmania reference strain L. infantum Mon-1 (MHOM/FR/78/LEM75), PCR with primer pair R221/R332 can detect 0.12 genome Leishmania/PCR tube, a limit detection that was not satisfactory compared to the value reported by authors using the same primer pair 0.05 (Lachaud et al., 2000), 0.07 (Chargui et al., 2005).

Regarding the second PCR assay with Lei70L/Lei70R, the lowest detection threshold was 0.01 , a result that is in agreement with the best values reported by authors using the same method 0.01 (Spanakos et al., 2002) or different methods 0.01 (Lachaud et al., 2002); then it was considered highly satisfactory compared to the first PCR assay used (R221/R332) and to those of other studies reported (Lachaud et al., 2000).

In this study, we assess the value of two optimised PCR methods (R221/R332 and Lei70L/Lei70R) compared with classical methods for the diagnosis of pediatric visceral leishmaniasis.

The mean age, sex ratio and clinical features of the present patients are similar to those reported by other studies on pediatric Mediterranean VL (Minodier \& Garnier, 2000; Cascio et al., 2002; Tanir et al., 2006; Cruz et al., 2006).

For all cases, diagnosis was established by PCR assays whereas classic methods remained positive for 44 cases by culture and for 42 cases by direct examination.

Both PCR analysis of peripheral blood yielded better results $(88,7 \%)$ than NNN culture $(41,5 \%)$ and LCC (7,5\%). Therefore, PCR assays performed on bone marrow were capable of detecting Leishmania DNA in 51 of 53 samples $(96,2 \%)$, whereas parasites were isolated by NNN culture in 37 of 53 samples $(69,8 \%)$ and amastigotes forms were observed in 42 out of 53 smears $(79,2 \%)$ and in 17 out of 53 LCC slides (32\%).

VL diagnosis with NNN culture and microscopic examination was established exclusively by bone marrow samples that require an invasive procedure. Direct examination has the advantage of being rapid and simple but it requires an efficient microscopic practice (Berman, 1997), and time-consuming microscopic examination (Da Silva et al., 2005).

If bone marrow samples are obtained, culture generally yields positive results from $70 \%$ to $81 \%$ (Lachaud et al., 2000; Costa et al., 1996; Berman, 1997; Belhadj et al., 2002, 2005).

Therefore, the limitation of culture performed on bone marrow and/or blood is that it requires a much longer time (four weeks) before declaring negative results. 
Regardless of LCC, it is less sensitive, due to the maximum speed of the cytospin which is probably not enough to complete the sedimentation of elements of such a small size as Leishmania, moreover the use of hemolized solution may damage the morphology of the parasite. Due to its lack of efficiency, it has rarely been used in the search for Leishmania in kala-azar cases from the Mediterranean region (Petithory et al., 1997; Ben Said et al., 1998).

Over all, higher sensitivities were obtained with PCR analysis performed on peripheral blood and/or bone marrow samples.

These present results are in agreement with those reported by other authors. In fact, Cruz et al., 2006 reported that Leishmania DNA was detected in peripheral blood in 19 of 24 patients $(79 \%$ ) and in bone marrow for all patients studied (100\%) and considered that PCR analysis was the most sensitive method compared to NNN culture (44\%) and bone marrow smears (67\%). Sensitivities of PCR performed in blood and bone marrow found by Antinori et al., 2007 were respectively $97.1 \%$ and $96.4 \%$, and were superior to the conventional techniques (sensitivities of culture and microscopic examination were $76.6 \%$ and $88.8 \%$ ).

Brustoloni et al., 2007 reported that among 91 pediatric VL, PCR analysis performed in Giemsa-stained slides was positive in 84 , yielding a sensitivity of $92.3 \%$; whereas bone marrow aspirates microscopy yielded a sensitivity of $79.1 \%$ and culture a sensitivity of $59 \%$. Regarding PCR assays, we have to prove the efficacy of the PCR with primer pair Lei70L/Lei70R versus that of PCR R221/R332.

We found that PCR Lei70L/Lei70R (Spanakos et al., 2002) amplifying a $345 \mathrm{pb}$ DNA fragment was positive in all cases ( 53 children) and concordant with microscopy and/or culture whereas PCR R221/R332 (Van Eys et al., 1992); producing a 603 pb DNA fragment was positive in only 40 cases.

PCR Lei70L/Lei70R performed on bone marrow had an excellent sensitivity $96.2 \%$ compared to the sensitivity of $75.5 \%$ for the first primer pair R221/R332. Then, the first PCR assay was highly satisfactory compared to the results reported (Cruz et al., 2006; Antinori et al., 2007; Brustoloni et al., 2007; Cascio et al., 2002; Lachaud et al., 2000; Mathis \& Deplazes, 1995; Costa et al., 1996; Katakura et al., 1998; Minodier et al., 1997; Nuzum et al., 1995; Piarroux R. et al., 1994). Perhaps, its specificity was 92,3\% versus that of the PCR R221/R332 $100 \%$. Regarding peripheral blood, the difference between the sensitivities of the two PCR methods is statistically significant (sensitivities: Lei70L/Lei70R $86.8 \%$ versus PCR R221/R332 $17 \%$ with p-value 0.025). Specificities of both methods were $100 \%$ (no false-positive result was observed in peripheral blood specimens from the 15 negative control patients tested either with PCR Lei70L/ Lei70R or PCR R221/R332).
These results can be explained by the ability of PCR Lei70L/Lei70R to detect very small numbers of parasites (0.012) demonstrated in experiments using serial dilution of Leishmania whereas the limit detection of PCR R221/R332 was 0.12. In fact, Spanakos G. et al., 2002 considered that the low detection limit of this PCR-method (Lei70L/Lei70R) can be attributed mainly to the design of the primers (high melting temperature was selected for the primers, resulting in less primer-target dissociation during the transition from annealing to elongation temperature and less primerdimmer formation).

Furthermore, less sensitivity of PCR R221/R332 was not due to the few or no circulating Leishmania parasites in pediatric patients with Mediterranean visceral leishmaniasis (Antinori et al., 2007; Lachaud et al., 2000, 2001, 2002; Minodier et al., 1997; Le Fichoux et al., 1999) nor to the presence of residual amounts of hemoglobin (Cascio et al., 2002; Adhya et al., 1995) (Spanakos et al., 2002 confirm that inhibition is a rare phenomenon), since 37 samples were scored negative with this assay whereas the parasite was detected with the primer pair Lei70L/Lei70R.

On the whole, the PCR Lei70L/Lei70R detection of pediatric visceral leishmaniasis using blood presents considerable advantages; in particular, its high sensitivity compared with PCR R221/R332 and with conventional methods. Moreover, the requirement of less invasive sample using peripheral blood has the advantages of being straight forward and easily repeatable compared with bone marrow for screening and for post therapeutic monitoring.

\section{CONCLUSION}

W e showed PCR Lei70L/Lei70R to be both specific and more sensitive than PCR R221/ R332 and classical methods, moreover, it can be performed on any biological sample especially on peripheral blood. We suggested that visceral leishmaniasis diagnosis should be applied firstly by PCR Lei70L/ Lei70R in peripheral blood and if it is not established, sternal puncture can be used.

\section{REFERENCES}

Adhya S., Chatterjee M., Quamarul Hassan Md., Mukherjee S. \& SEN S. Detection of Leishmania in the blood of early kala-azar patients with the aid of the polymerase chain reaction. Transaction of the Royal Society of Tropical Medicine and Hygiene, 1995, 89, 622-624.

Antinori S., Calattini S., Longhi E., Bestetti G., Piolini R., Magni C., Oralando G., Gramiccia M., Acquaviva V., Foschi A., Corvasce S., Colomba C., Titone L., Parravicini C., Cascio A. 
\& Corbellino M. Clinical use of polymerase chain reaction performed on peripheral blood and bone marrow samples for the diagnosis and monitoring of visceral leishmaniasis in HIV-infected and HIV-uninfected patients: a single center, 8-year experience in Italy and review of the literature. Clinical Infectious Diseases, 2007, 44, 16021610 .

Ayadi A., Ben Ismail R. \& Ben Rachid M.S. Extension de l'aire de transmission de Kala-Azar à L. infantum (Nicolle, 1908) vers le centre et le sud de la Tunisie. Archives de l'Institut Pasteur de Tunis, 1991, 68, 269-273.

Belhadj S., Hicheri Helali J., Kallel K., Kaouech E., Abaza A., Toumi N.H., Dakhlia H., Hammami M., Ben Chaabane T. \& Chaker E. Place de la culture dans le diagnostic parasitologique des leishmanioses viscérales et cutanées : expérience tunisienne. Revue française des laboratoires, 2005 , 369, 41-45.

Belhadj S., Pratlong F., Mahjoub H., Toumi N.H., Azaiez R., Dedet J.P. \& ChaKer E. Leishmaniose viscérale infantile à Leishmania infantum Mon-24 : une réalité en Tunisie. Bulletin de la Société de Pathologie Exotique, 2000, 93 (1), 1213.

Belhadj S., Pratlong F., Toumi N.H., Kallel K., Mahjoub H., Babba H., Azaiez R., Dedet J.P. \& Chaker E. Visceral leishmaniasis in Tunisia: result of the isoenzymatic characterization of 65 leishmania infantum strains. Transaction of the Royal Society of Tropical Medicine and Hygiene, 2002, 96, 627-630.

Belhadj S., Toumi N.H., Dakhlia H., Kallel K., Boussen N., Ben ChaAbane T. \& Chaker E. La culture du sang périphérique comme moyen diagnostique de la leishmaniose viscérale : à propos de 61 cas. Médecine Tropicale, 2002, 62 (2), 155-157.

Ben Said M., Amri F., Mili A., Ardoin F. \& Petithory J.C. La cytoconcentration appliquée au diagnostic de la leishmaniose viscérale chez l'enfant immuno-compétent. Communication préliminaire d'une étude faite en Tunisie. Bulletin de la Société Française de Parasitologie, 1998, 16 (1), 86-94.

Berman J.D. Human leishmaniasis: clinical, diagnostic and chemotherapeutic in the last 10 years. Clinical Infectious Diseases, 1997, 24, 684-703.

Brustloni Y.M., Lima R.B., Venancio da cunha R., Dorvl M.E., Oshiro E.T., Lyrio de oliveira A.L. \& Pirmez C. Sensitivity and specificity of polymerase chain reaction in Giemsa-stained slides for diagnosis of visceral leishmaniasis in children. Memorias do Instituto Oswaldo Cruz, 2007, 102, 4 .

Bouratbine A., Aoun K., Chahed M.K. \& Ben Ismail R. Données épidémiologiques sur la leishmaniose viscérale infantile en Tunisie en 1993. Médecine et Maladies Infectieuses, 1998, 28, 446-447.

Cascio A., Calattini S., Colomba C., Scalamogna C., Galazzi M., Pizzuto M., Camilli R., Gramiccia M., Titone L., Corbellino M. \& ANTINORI S. Polymerase chain reaction in the diagnosis and prognosis of mediterranean visceral leishmaniasis in immunocompetent children. Pediatrics, 2002, 109 (2), 27.

Chargut N., Bastien P., Kallel K., Haouas N., Messaidi Akrout F., Masmoudi A., Zili J., Chaker E., Dhahri Ben Osman A.,
Azaiez R., Crobu L., Mezhoud H. \& Babba H. Usefulness of PCR in the diagnosis of cutaneous leishmaniasis in Tunisia. Transaction of the Royal Society of Tropical Medicine and Hygiene, 2005, 99, 762-768.

Costa J.M., Durand R., Deniau M., Rivollet D., Izri M., Houin R., VIDAUd M. \& BRETAGNE S. PCR Enzume-linked immunosorbent assay for diagnosis of leishmaniasis in human immunodeficiency virus-infected patients. Journal of Clinical Microbiology, 1996, 34 (7), 1831-1833.

Cruz I., Chicharro C., Nieto J., Bailo B., Canavate C., Figueras M.C. \& Alvar J. Comparison of new diagnostic tools for management of pediatric Mediterranean visceral leishmaniasis. Journal of Clinical Microbiology, 2006, 2343-2347.

Da Silva M.R., Stewart J. \& Costa C.H. Sensitivity of bone marrow aspirates in the diagnosis of visceral leishmaniasis. American Journal of Tropical Medicine and Hygiene, 2005, 76 (6), 811-814.

DiRECTION DES SOINS DE SANTÉ DE BASE. Les huitièmes journées nationales de santé publique. Table ronde : la lutte contre les leishmanioses. Nabeul, 21, 22, 23 septembre 2000.

Katakura K., Kawazu S.I., Naya T., Nagakura K., Ito M., AiKawa M., Qu J.Q., Guan L.R., ZuO X.P., Chai J.J., Chang K.P. \& Matsumoto Y. Diagnosis of Kala-Azar by NestedPCR based on amplification of the leishmania mini-exon gene. Journal of Clinical Microbiology, 1998, 36 (8), 21732177.

Lachaud L., Chabbert E., Dubessay P., Reynes J., Lamothe J. \& BASTIEN P. Comparison of various sample preparation methods for PCR diagnosis of visceral leishmaniasis using peripheral blood. Journal of Clinical Microbiology, 2001, 39 (2), 613-617.

Lachaud L., Dereure J., Chabbert E., Reynes J., Mauboussin J.M., Oziol E., Dedet J.P. \& Bastien P. Optimized PCR using patient blood samples for diagnosis and follow-up of visceral leishmaniasis, with special reference to AIDS patients. Journal of Clinical Microbiology, 2000, 38 (1), 236-240.

Lachaud L., Machergui- Hammami S., Chabbert E., Dereure J., DedeT J.P. \& BAstien P. Comparison of six PCR methods using peripheral blood for detection of canine visceral leishmaniasis. Journal of Clinical Microbiology, 2002, 40 (1), 210-215.

Lanotte G., Rioux J.A., Maazoun R., Pasteur N., Pratlong F. \& LEPART J. Application de la méthode numérique à la taxonomie du genre Leishmania Ross, 1903. À propos de 146 souches originaires de l'Ancien Monde. Utilisation des alloenzymes. Corollaires épidémiologiques et phylétiques. Annales de Parasitologie Humaine et Comparée,1981, 56, 575-592.

Laveran L. \& Cathoire M. Présentation de parasite : Piroplasma donovani. Bulletin de l'Académie de Médecine, 1904, 51, 247-248.

Le Fichoux Y., Quaranta J.F., Aufeuvre J.P., Lelievre A., Marty P., Suffia I., Rousseau D. \& Kubar J. Occurrence of Leishmania infantum parasitemia in asymptomatic blood donors an area of endemicity in southern France. Journal of Clinical Microbiology, 1999, 37 (6), 1953-1957.

Mathis A. \& DePlazes P. PCR and in vitro cultivation for detection of leishmania spp. in diagnostic samples from humans and dogs. Journal of Clinical Microbiology, 1995, 33 (5), 1145-1149. 
Minodier P. \& GARnier J.M. La leishmaniose viscérale infantile en Provence. Archives de Pédiatrie, 2000, 7 (3), 572577.

Minodier P., Piarroux R., Gambareli F., Joblet C. \& Dumon H. Rapid identification of causative species in patients with old world leishmaniasis. Journal of Clinical Microbiology, 1997, 35 (10), 2551-2555.

Nuzum E., White III F., Thakur C., Dietze R., Wages J., Grogl M. \& Berman J. Diagnosis of symptomatic visceral leishmaniasis by use of the polymerase chain reaction on patient blood. Journal of Infectious Diseases, 1995, 171, 751-754.

Petithory J.C., Ardoin F., Ash L.R., Vandemeulebroucke E., Galeazzi G., Dufour M. \& Paugam A. Microscopic diagnosis of blood parasites following a cytoconcentration technique. American Journal of Tropical Medicine and Hygiene, 1997, 57 (6), 637-642.

Piarroux R., Gambarelli F., Dumon H., Fontes M., Dunan S., Mary C., Toga B. \& Quilici M. Comparison of PCR with direct examination of bone marrow aspiration, myeloculture, and serology for diagnosis of visceral leishmaniasis in immuncompromised patients. Journal of Clinical Microbiology, 1994, 32 (3), 746-749.

Pratlong F., Martini A., Lambert M., Lefebre M. Dedet J.P. \& Rioux J.A. Intérêt de la culture et de l'identification isoenzymatique des leishmanies dans le diagnostic et l'épidémiologie des leishmanioses. Médecine et Armées, 1994, 22 (1), 61-65.

Schaefer K.U., Schoone G.J., Gachihi G.S, Muller A.S., Kager P.A. \& Meredith S.E.O. Visceral leishmaniasis: use of the polymerse chain reaction in an epidemiological study in baringo district, Kenya. Transactions of the Royal Society of Tropical Medicine and Hygiene, 1995, 89, 492-495.

Spanakos G., Pastoula E., Kremastinou T., Saroglou G. \& VAKalis N. Development of a PCR-based method for diagnosis of leishmania in blood samples. Molecular Cell Probes, 2002, 16 (6), 415-420.

TAnir G., Taylan ÖZkan A. \& Daglar E. Pediatric visceral leishmaniasis in Turkey. Pediatrics International, 2006, 48 (1), 66-69.

Van Eys G.J.J.M., Schoone G.J., Kroon C.C.M. \& Ebeling S.B. Sequence analysis of small subunit ribosomal RNA genes and its use for detection and identification of leishmania parasites. Molecular and Biochemical Parasitology, 1992, 51, 133-142.

Reçu le 24 mai 2007 Accepté le 16 janvier 2008 